\title{
Research on innovation ability of general undergraduate education
}

\author{
Huang shuli, Mu zhendong \\ College of Information Engineering, Jiangxi College of Technology, Jiangxi Nanchang 330098
}

Keywords: Innovation ability; General undergraduate; Computer Science Teaching

\begin{abstract}
Technology development today, innovation is the core power technology development, innovation is the key person, plenty of good and innovative professional and technical personnel is essential to achieve organizational virtuous cycle "Innovation - Innovation - benefit." Youth are strong, the country is strong, as the innovation ability of young college student is the main country strong fundamental, how to improve the scientific and technological innovation ability of colleges and universities is a central issue in higher education. In this paper, computer science education, for example, explains how to provide students with the ability to innovate.
\end{abstract}

\section{Introduction}

It is technological development and technological innovation, making society from an agricultural economy to an industrial economy, society and knowledge of economic and social development of human society. Took advantage of the opportunities afforded by technological development, making the rapid rise in some countries become a world power.

18th century steam engine started the first industrial revolution, the British manufacturing industry, construction, maritime and so began to use the machine, get rapid development, and soon became the world's number one capitalist powers;

19th century to the 20th century electrical and chemical also caused a second industrial revolution, mankind has entered electrification, nuclear and aerospace aviation era. 19th century to complete reunification of Germany, to seize the opportunity of the industrial revolution, the rapid rise as a world power.

The second half of the 20th century, in full swing IT triggered the third industrial revolution, social production and consumption to automation, intelligent, knowledgeable transition from the era of industrialization, again greatly improved productivity, labor productivity has been greatly again leap. United States to use a second chance and a third industrial revolution, the rapid development of the world's only superpower.

Faced with the new trend of science and technology for economic development, not only in developed countries, but also major developing countries, have made a similar strategic choice, that scientific and technological innovation as a national strategy. The main concern from the past scramble for natural resources to expand to compete for knowledge and human resources, and the scientific and technical knowledge as an important strategic resources to develop and enhance the capability of independent innovation as the basic national strategy, increasing government finances Technology investment, ahead of the deployment and development of strategic technologies, to nurture and develop their own technological capabilities. 


\section{China Innovation urgency}

Lack of technological innovation capability has become the soft underbelly of China's economy, which is a substantial improvement in the Chinese economy juncture of international competitiveness must get past. High consumption, high pollution and low efficiency threat to China's sustainable development. Now, China is a big country consumption of resources, but our unit 1/10 inadequate resources average output in developed countries; China is the third largest country in the world trade, but exports have accounted for only 10 percent of independent brands and intellectual property; China is manufacturing country, but mainly by the introduction of important technical equipment; Chinese high-tech exports continue to increase, but not only dependent on imports of key components, but also to pay high fees to foreign companies annually for software technology standards. China's electronic information industry is a big country, but in 2004 the average profit margin of China's top 100 electronic enterprises, only 4.07\%, while Microsoft is 28 percent, Intel is $21.9 \%$, $18.8 \%$, Samsung, Nokia is $14.7 \%$. Therefore, do not break the bottleneck of technological innovation capability, economic strength and competitiveness of the country's business can not be really improved.

1, China's ability to technological inventions too low. 1/4 patents for Korea, the US, Japan, 1/30. The number of patents granted each year a lot of invention patents accounted for only one-third and half of foreign intellectual property rights belong to the inventor.

2 , the foreign economic activity in our country has occupied a "dominant" status. In 2003, foreign companies accounted for $54 \%$ of China's imports and exports, accounting for $68 \%$ of the mechanical and electrical exports, accounting for $85 \%$ of high-tech exports. If you do not attach importance to innovation, it seems there is a "torso national" momentum.

3 , most industries are lack of core technology. The main source of technology machinery $57 \%$ dependent on imported, most of the core technology of electronic information devices rely on foreign countries.

4, weak awareness of technological innovation. 28,000 medium-sized enterprises nationwide to engage in R \& D activities, only 25 percent; the remaining $75 \%$ of the companies do not specialize in technology research and development staff; half of medium-sized enterprises can not be held once a year science and technology activities. Less R \& D investment, R \& D expenditures of enterprises in China in less than $1 \%$ of sales, the proportion of foreign companies is less than $3 \%$, but less than $7 \%$ to $10 \%$ the proportion of foreign high-tech enterprises. Industry has long been cured on low-skill, low value-added sectors. Our footwear exports to the US, FOB average price of \$2-3, while the US market price of about $\$ 50$, for each of our products to earn 10 to 20 cents a pair of shoes. $74 \%$ of the top 200 foreign trade through processing trade enterprises failed to become the main innovation, competitiveness is low, in the production of low energy consumption, the plight of the device dependent.

5. Repeat the introduction of technology without attention to digestion and absorption. According to statistics, the introduction of technology investment and the digestion and absorption ratio: Japan 1: 7; Korea is 1: 5; China is 1: 0.07. Big difference, enough to explain technical dependence is too strong.

6, the split between the innovative elements of each other, it is difficult to display a comprehensive national innovation capacity. 


\section{Innovative training approach}

Young people are the future of the country, colleges and universities and more students are the future of the country, so the train college students ability to innovate, is a major way to enhance the country's competitiveness. Our university education from the beginning of the scores of education to quality education, and now it is proposed innovative education, the education of college students innovative consciousness for the first time to a strategic level. As a college teacher, innovative educational mission of our university students can be enhanced from the following aspects:

To improve university to recognize the importance of innovation capability. Today, China's universities is being divided into two kinds of university academic and skills, which are the basis of academic research-based, and skill type is mainly from the technical knowledge to master. So many universities granted that innovation only academic university should do, and as the broader skills as long as the university is self-related technical proficiency can be, there is no innovation, research and therefore do not pay attention, do not pay attention to new products technology research. This understanding will greatly harm the students' awareness of innovation, skills-based universities from inventions, new technology research in a variety of ways to innovate, encourage teachers and students to study various aspects.

The introduction of new elements in the teaching methods and content. It has been said that most of the primary education is the knowledge of thousands of years ago, hundreds of years ago, the majority of high school education knowledge, knowledge of mostly university knowledge hundred years ago. The impact of this trend is to bring scripted university teachers on teaching, not simply introduce new knowledge, but also not concerned about the development of technology, students learn out of this vision is limited, do not grasp the latest developments, thinking it very rigid, so in order to improve students' ability to innovate, introducing innovative elements must, for example, the introduction of sound teaching methods, video, on-site and other means, in the teaching content and more content to introduce cutting edge of technology.

Increase the impact of the subject. In many university teachers have participated in the relevant research group, and they all have their own subject-related topics, some basic research on these topics, some external projects, today's universities, these topics are either teachers themselves in the study, led by some of the students either completed undergraduate students rarely have the opportunity to participate in, but as a young, these students just in curiosity heaviest period, novelty and innovation for the most enthusiastic study period, so if you can absorb a large number of undergraduate students to join the research, the greatly stimulate their innovative research.

Open laboratories to attract more students. Today the University has a large number of laboratories, which in many cases in order to ensure the safety of experimental equipment, rarely open to undergraduates, graduate students and is open only to teachers, but the equipment is dead, people are living, for some dead thing and limit the use of students, you can not maximize the value of equipment. In order to make students more access to new tools, new technologies, the creation of an open laboratory, attracting college students into the laboratory to participate in various research activities is the way to improve the innovation ability of university students.

The creation of innovative incentives Students. For graduate students, our country has a wide variety of scholarships and graduate students published innovations have funded a variety of research funds, but the students, such financing is very rare, for example, students sent papers, college students published patents, which in our country, or need some money, if you want to university students at their own expense, will undoubtedly add to their burden, reducing their enthusiasm. 


\section{Acknowledgements}

This work was financially supported by project of Technology Department of Jiangxi Province [No 2013BBE50051].

\section{References}

[1]The international handbook on innovation[M]. Elsevier, 2003.

[2]Wan Y, Jiang G. On Robot-based Education and Innovation Ability Training for College Students [J]. Journal of Electrical \& Electronic Engineering Education, 2005, 4: 001.

[3]CHEN D, SUN E. Opening Teaching Iaboratories Raising Innovation Ability of students [J]. Laboratory Research and Exploration, 2001, 2: 005.

[4]Janszen F. The age of innovation[J]. Financial Times/Prentice Hall, London, 2000.

[5]Wei-wu Z. Research on Cultivating Pratice and Innovation Ability for undergraduate [J]. Experimental Technology and Management, 2006, 1: 031.

[6]LIU H, LIANG D. The Cointegration Analysis between the R\&D Input and the Independent Innovation Ability [J]. Science of Science and Management of S. \& T, 2006, 8: 005.

[7]LIU X, HU Z. The pattern of China regional innovation capability and its implication [J]. Studies In Science of Science, 2002, 5: 021.

[8]Wei-wu Z. Research on Cultivating Pratice and Innovation Ability for undergraduate [J]. Experimental Technology and Management, 2006, 1: 031. 